\title{
EFFECTS OF CHICKERING-GAMSON INSTRUCTIONAL STRATEGY ON UNDERGRADUATE STUDENTS' ACHIEVEMENT IN EDUCATIONAL MANAGEMENT CONCEPTS IN FEDERAL UNIVERSITIES IN SOUTH-EAST, NIGERIA
}

\author{
DR FRANCISCA N. OGBA ${ }^{1}$, PROF. CHRISTIANA A. UGODULUNWA ${ }^{2}$, DR IHEANYI O. IGWE \& $^{3}$ \\ UKAMAKA F. IREMEKA ${ }^{4}$ \\ ${ }^{1,2}$ Department of Educational Foundations Federal University Nufu-Alike Ikwo Ebonyi State, Nigeria \\ ${ }^{3}$ Department of Science Education, Faculty of Education, Ebonyi State University, Abakaliki \\ ${ }^{4}$ Department of Educational Foundations, University of Nigeria
}

\begin{abstract}
In teaching and learning of Educational Management concepts, both the lecturer and the student have their different roles to play so as to attain the objectives of a given classroom curriculum. It is very important that an appropriate instructional strategy be adopted in teaching Educational Management to improve the achievement of lesson objectives. Across the Universities, performance has been low which has been blamed on the use of inappropriate instructional strategy. This study therefore investigated "effects of Chickering-Gamson instructional strategy on undergraduate students' achievement in Educational Management concepts in Universities in the South-East Zone, Nigeria. Chickering -Gamsonlearning strategy has its base on composite principles which are encapsulated into a constructive model that is learner-centered. Quasi experimental design was adopted involving prettest-posttest non-equivalent control group condition. The target population comprised undergraduate students from Faculties of Education in Universities in the South East Zone, Nigeria. A sample of one hundred and fifty nine (159) students from intact classes was used for the study. The Instrument for data collection was Educational Management Achievement Test (EMAT). The instrument comprised a multiple choice test items numbering thirty four (34). The instrument was validated by three experts; two in Educational Management while one was from Measurement and Evaluation, all from Federal University, Ndufu-Alike Ikwo in Ebonyi State. Item analysis involving Difficulty index and Discriminating power was carried out whereby four (4) items were dropped, leaving 30 items for use. Kuder-Richardson 20 formula (Kr-20) was used to determine the reliability coefficient as 0.91, which showed very high internal consistency. Three research questions were formulated to guide the study and three null hypotheses were tested at 0.05 level of significance. Mean and standard deviation were used to answer the research questions while Analysis of Covariance (ANCOVA) was used to test the hypotheses. Findings from the study showed that: Students in Chickering-Gamson Instructional Strategy group had higher achievement than those in the Lecture Method group; male undergraduate students had a higher mean score than the female students in the Chickering - Gamson Instructional Strategy group; there was no interaction effects of teaching strategies and gender on students' achievement mean score. Hypothesis one $\left(\mathrm{HO}_{1}\right)$ was significant while hypotheses $\left.\mathrm{two}_{(\mathrm{HO}}\right)$ and three $\left(\mathrm{HO}_{3}\right)$ were not significant. Based on the findings, it is recommended that Chickering-Gamson Instructional Strategy should be used in teaching Educational Management concepts in the Universities but other undergraduate courses as well.

KEYWORDS: Chickering-Gamson, Instructional, Strategy, Undergraduates, Lecture, Achievement
\end{abstract}

Received: Jun 08, 2020; Accepted: Jun 28, 2020; Published: Sep 16, 2020; Paper Id.: IJMPERDJUN20201292 


\section{INTRODUCTION}

Educational institutions all over the world are going through a lot of changes in teaching, learning, assessment and accountability. These changes are as a result of technological innovations, diversity, environment, politics and policies which have affected various instructional strategies used for instruction in the universities. These changes have also forced higher institutions to undergo paradigm shifts with the view to making teaching and learning more meaningful, learnercentered, self-directed, creative and innovative. These paradigm shifts coupled with the emphasis on teaching skills for knowledge construction rather than knowledge acquisition have mounted pressure on lecturers in the Universities to strive to make leaning activity driven, usually from more experienced person to less experienced person. Teaching according to Duarte (2013) is a process which involves helping students to create knowledge through interactive and authentic learning experiences. The teacher's role is to guide students toward useful experiences that facilitate meaningful learning outcomes. Igwe (2013) maintained that direct instructional activities where students passively assimilate knowledge are usually minimized in an activity based class.

Teaching for understanding and problem solving requires engaging students with content flexible and innovative ways of learning (Wayant (2003). Ogba and Igu (2015) affirmed that teaching methods that promote students' critical thinking equally tend to sustain students' interest in learning for improved performance. The above assertions give room to the key features of a good learning environment where authentic instructional tasks that encourage students' collaboration among peers and multiple learning activities are enhanced. This situation will help to facilitate the purpose of education that centered on creativity, innovation through conceptualization, analysis, synthesis and application of previous experience by which, new knowledge is created (Meyer, 2009 and Lombardi, 2011). Bain (2012) maintained that the professional responsibility of teachers is to ensure that teaching promotes deep learning that infuses creativity. Ugodulunwa, Ogba and Igu (2017), Ogba and Igu (2013) and Ituma, (2012) maintained that good teaching entails commitment to providing constructive feedback to students which has been proved to enhance learning, promote self assessment, make students aware of their areas of needs, strengths and weaknesses thereby helping teachers to give advice on how to improve performance.

According to the Oxford English Dictionary cited in Igwe (2013), management is a skilful treatment or control of business or a household. Management applies to lots of concern according to needs including education. Therefore, in the context of this study, Educational Management is a process of utilizing human and material resources through the functions of planning, organizing, directing, leading and controlling to achieve educational outcomes. It plays vital roles in the society in the sense that it helps to produce knowledgeable, skilful, dynamic and value driven teachers and other professionals (Managers) who can match their peers nationally and internationally. These researchers feel that this is the need of the $21^{\text {st }}$ Century when resources are so vast that specialized managers are required to handle and manage such resources.

Sequel to the relevance of Educational Management in the development of individuals as professional or expert managers, it offered as a course of study in the Universities and in the preliminary year of the students. Various methods or strategies are used to implement or teach the course such as excursion, project, inquiry, scalfolding, concept mapping, and lecture (Ewah, 2016). From the results of this course over the years, the performances of students have been poor. For instance, in 2017/2018 session, a total of four hundred and three (403) students took the first semester examination in Educational Management. Out of this number, 77 students or $18.40 \%$ got credit; 81 students or $20.10 \%$ got pass and 248 
students or $61.50 \%$ failed out-rightly (computed from the data from the Universities). This is not a welcome situation considering the importance of Educational Management in the economic development of the nation and the South East Zone in particular. The use of Lecture Teaching Method in teaching, especially in Universities has been blamed for the abysmal poor performance of students in Educational Management which calls for an urgent search for other teaching methods that are innovative, activity base, hands-on, and interactive to use in teaching the course.

Based on this search for a strategy that meets the above criteria, these researchers decided to employ the Chickering-Gamson Instructional Strategy in this study in teaching Educational Management to determine its effects on undergraduate students' level of achievement. It is believed that this strategy will constitute one of the good teaching practices or strategies in higher institutions as demanded by other scholars (Chickering \& Gamson, 1987; Prosser and Trigwell, 1999; Biggs 2004; Brookfield, 2006; Light and Calkins, 2008). It is also to be noted that teaching in higher institutions according to (Devlin and Samarawickrema, 2010;Duarte, 2013) is a complex activity. It does not seem to have any universally accepted definitions but is carried out through pedagogical techniques that are essential elements in enhancing teaching and learning processes (Igwe and Igwe, 2017).

Chickering-Gamson Instructional Strategy is a constructivist influential method of teaching and learning developed in 1987 to enhance students' active participation in teaching-learning process. This instructional strategy is encapsulated in the "seven principles of good practice in undergraduate education" which a lecturer should implement to make teaching more meaningful to undergraduate students. These seven principles which constitute the seven steps of the instructional strategy are:

- Encouraging contacts between students and faculty

- Developing reciprocity and cooperation among students

- $\quad$ Using active learning techniques

- Giving prompt feedback

- Emphasizing time on task

- Communicating high expectations, and

- Respecting diverse talents and ways of learning of the students.

Briefs on the seven steps (Principles) of Chickering-Gamson Strategy are:

Step 1- encouraging contacts between students and faculty is a vital factor in students' motivation because it helps students get through rough times and keep track on learning. It embodies situations of friendship, accessibility and enthusiasm. According to Chickering and Ehramann (1996), keeping such contacts enhance students' intellectual commitment and encourage them to learn, think valuably and plan well.

Step 2- Developing reciprocity and cooperation are collaborative in nature which enhances social interaction (meeting) that fosters good learning habits. Reciprocity and cooperation tend to reduce unnecessary competitiveness and isolation that lead to frustration according to Pallof(2009). According to Devlin and Samatawickrema (2010), integrating cooperation activities in teaching prompts within and across discussions among teams, thereby encouraging participation and satisfaction in teaching and learning processes. 
Step 3-The use of active learning techniques increase involvement, productivity and enhances self esteem. The principle of active participation explains that learning is not a spectator sport. It embodies study grouping, debates and project approach. It is very essential for students to talk about what they have learnt, reflect on them, relate it to past experiences and apply what they learnt in novel situations (Pallof, 2009). Chiu, Young, Liang and Chen, (2010) maintained that students must participate actively in a group; share ideas, explain their opinions, articulate their reasoning and expound their knowledge.

Step 4- giving prompt feedback strengthens students trust in relations to students' achievements and satisfactions. It embodies re-planning a lesson for remediation; expressing concern for the aspects of topic that was not properly treated; and appreciation of the aspects that one performed creditably. Actually, students are encouraged when they receive feedback on performed task which helps them to take corrections for better future performance.

Step 5 -Emphasis on time on task deals with aspects of punctuality, sticking to time approved and allotted to a lesson; and being conscious of the duration for a particular lesson. Time on task is critical because it leads to effective teaching and learning for both professional and students alike (Cakiroglu, 2014 and Sherry 2014). It calls for time management which is important in teaching-learning situation and forestalls clashes between lecturers.

Step 6- Communicating high expectations to students is important for all categories of students (bright students, poorly prepared, interested, not interested). It instills in the students the need to develop positive attitude; creating a dialogue box for exchange of ideas among students and knowing the students by name. Communicating high expectations to students helps in energizing students' self fulfillment and sufficiency.

Step 7- Respecting diverse talents and ways of learning explains that students learn in unique ways. These understanding would encourage reward of creativity; employing various techniques to execute the teaching; and being sensitive cultural differences of the students for equal attention in the lecture halls. Effective teaching must recognize and address differences in students' abilities and learning.

It thus appear that the seven steps instructional strategy has the potential to empower six vital elements in education which are interaction, responsibility, activity, cooperation, expectation and diversity among students as to encourage proper learning and higher achievement. The researchers believe that the Chickering-Gamson Instructional Strategy is capable of promoting quality standards in teaching so as to make students to have an in-depth understanding of what is being learned. The lecturer's role here is only to mentor the student to be creative, solve problems in enabling learning environment to modify their existing knowledge and allow for creation of new knowledge in the teaching-learning process. These researchers equally believe that these steps when duly followed would definitely propel good learning habits in students, encourage self-esteem and confidence for knowledge creation and enhanced academic performance of undergraduate students in the Universities in South-East, Nigeria.

Another method of instruction in this study is the Lecture Teaching method, which served as the Control. Some studies have demonstrated that instructors in the traditional classes still rely heavily on didactic teaching methods (teacher centred) such as Lecture teaching method. This method neither encourages learner-centered activities nor promotes a deeper understanding in teaching and learning processes (Smith and Valentine, 2012). The lecture scenario could culminate into rote learning that produces knowledge that is not retained for a long time (Igwe, 2013). It does not 
encourage good learning habit that normally involves continual reflection on the processes of teaching which lay the foundation for fostering independent life learning skills.

Gender is an intervening variable in this study. Gender refers to the range of characteristics pertaining to and differentiating between masculinity and feminity. It is one of the factors in Educational Management achievement which has generated a lot of concern for students. According to Kahreci (2015), the relationship between gender and attitudes towards Educational Management is ambivalent. Gender is a socio-cultural constructed concept of ascribing characters and roles to masculine and feminine (Okeke, 2007). Oludipe (2012) noted that the prevalent effects of gender bias and gender stereotypes in Nigeria affect certain vocations and professions. The stereotyping bias that certain subjects are male enterprise is of great concern in the field of education and has resulted to controversial and conflicting reports from different researchers. For instance, Nwagbo and Chukelu, (2011) and Oludipe (2012) in their separate studies inferred that there exist no significant difference in the achievement of boys and girls in science while Nasr and Asghar (2011) and Okoro (2011) observed that a significant difference exists in the achievement of male and female students in science. Nzewi (2010) opined that both males and females achieve equally in science when given equal opportunity and facilities. Okoro (2011) maintained also that the use of some instructional strategies on individual learning basis favour male students more than females while those that encourage group work favour females more than males. Ajayi and Ogbeta (2017) observed that students' achievement is not dependent on gender but on methods, stressing that hands-on instructional method is superior to demonstration method irrespective of gender in fostering achievement in a subject matter.

In view of the above discussions, gender still remains an issue of contention in Nigeria education system today as educators have expressed diverse views about gender and achievement in school subjects. It does appear that gender as an influencing factor in learning and achievements in school subjects remains important and controversial. To investigate or justify those views, the researchers carried out a study on the topic "Effects of Chickering-Gamson Instructional Strategy on Undergraduate male and female students' Achievement in Educational Management in Federal Universities in South East Geo-political Zone of Nigeria.

On the basis of the theoretical framework, this study is rooted on the constructivism theory which explains how people acquire knowledge and learn. The study is premised on the notion that learners learn actively construct their own meaning and knowledge from experiences. The theory views teaching as a process that helps learners to create knowledge through interactive and socialistic learning processes. In this theory, the teacher's role is that of a facilitator who guides the students towards meaningful learning through gained experiences (Ituma, 2012). Teachers are expected to allow learners to construct knowledge which provides optimum guide. Major features of constructivist learning environment pedagogies include active learning, authentic instructional tasks, collaboration among students, diverse and multiple learning formats (Aydogdu, Doymus and Simsek, 2012). The Chickering -Gamson Instructional Strategy aligns with constructivist theory that emphasizes active learning to make room for creativity and innovation which are gained through analysis, conceptualization and synthesis of prior experiences. When all these are put into practice, they create new knowledge in the teaching-learning process.

\section{STATEMENT OF THE PROBLEM}

The necessity of making knowledge constructive has forced researchers and scholars to venture into the principles of good practice in education. Again, there has been persistent poor performance of students in Educational Management over the 
years and this has been attributed to the use of inappropriate instructional methods adopted by lecturers. Preliminary investigation from the various Universities in the South East Geo-political Zone revealed the existence of persistence mass failure in Educational Management. Many incidences of examination malpractices have been reported involving the students in an effort to pass the course at creditable level. This situation is a source of concern to these researchers who themselves are lecturers in the University.

The researchers fear that if the situation is not tackled promptly and solution proffered, many students may find it difficult to attain their cherished careers especially those wishing to be flight or Management Executives in business concerns and tertiary institutions. It is therefore needful to inject into the teaching of Educational Management an effective, interactive and innovative teaching strategy that would improve students' achievement in order to sustain their interest in their chosen careers.

The problem of this study therefore when framed in a question form is "what is the effect of Chickering-Gamson Instructional Strategy on Undergraduate students' achievement in Educational Management in federal Universities in South East Geo-political Zone, Nigeria.

\section{PURPOSE OF THE STUDY}

The main purpose of this study was to determine Effects of Chickering-Gamson Instructional Strategy on Undergraduate students' Achievement in Educational Management in Federal Universities in South East Geo-political Zone of Nigeria. Specifically, the study determined:

- The effect of Chickering-Gamson Instructional Strategy on Undergraduate Students' Achievement in Educational Management in Federal Universities in South East Geo-political Zone of Nigeria

- The effect of Chickering-Gamson Instructional Strategy on male and female Undergraduate Students' Achievement in Educational Management in Federal Universities in South East Geo-political Zone of Nigeria

- The interaction effect of teaching strategies and gender on Undergraduate Students' Achievement in Educational Management in Federal Universities in South East Geo-political Zone of Nigeria

\section{SIGNIFICANCE OF THE STUDY}

The findings of this study would be of immense benefit to lecturers, undergraduate students, curriculum planners, university authorities and future researchers.

To the students, the result would bring about the spirit of collaboration and cooperation thereby reducing the fear, frustration and failure which students experience in Educational Management. This would lead to higher achievement and many students would enroll into careers in Educational Management, thereby equipping themselves for relevant job opportunities.

To the teachers, the result would expose them to more effective techniques of promoting learning which would help to minimize students' low achievement in Educational Management.

To the curriculum planners, the result would enable them to plan Educational Management curriculum in such a way that the contents would be filled with activities which teachers and students would carry out together. 
The result would be relevant for curriculum reforms and improvement as it is in line with the National University Commission (NUC) curriculum benchmark which recommends student-centered pedagogy that can assist in achieving the national educational goals which include the acquisition of appropriate skills, mental, physical and social abilities and competence that would equip the individual to line in and contribute to the development of the society (Isiogu-Abanihe, 2017).

To University Authorities, the result would create room for organizing workshop, seminars and conferences for review of pedagogy in teaching-learning process to address the issues of integrating new ideas on teaching and learning of Educational Management.

To future researchers, the results would provide framework for further studies in Educational Management as well as provide materials for future researchers.

\section{SCOPE OF THE STUDY}

This study was delimited to Effects of Chickering-Gamson Instructional Strategy on Undergraduate students' Achievement in Educational Management in Federal Universities in South East Geo-political Zone of Nigeria. The subjects of the study were year one (1) Undergraduate students of Educational Management in Federal Universities in the South East Geopolitical Zone of Nigeria. The concepts treated in the study were: meaning, nature and scope of Educational Management in Nigeria; differences between Educational Management and Educational Administration, and goals and functions of Educational Management in Nigeria.

\section{RESEARCH QUESTIONS}

This study was guided by the following research questions.

- What is the achievement mean score of undergraduate students taught Educational Management using Chickering-Gamson instructional strategy and those taught using the Lecture Teaching Method?

- What is the achievement mean score of male and female undergraduate students taught Educational Management using Chickering-Gamson instructional strategy?

- What is the interaction effect of teaching strategies and gender on the achievement mean score of undergraduate students in Educational Management?

\section{Hypotheses}

The following null hypotheses were tested at 0.05 level of significance

- $\mathbf{H O}_{1}$ : there is no significant difference in the achievement mean score of undergraduate students taught Educational Management using Chickering-Gamson instructional strategy and those taught using the Lecture Teaching Method?

- $\mathbf{H O}_{2}$ : there is no significant difference in the achievement mean score of male and female undergraduate students taught Educational Management using Chickering-Gamson instructional strategy

- $\mathbf{H O}_{3}$ : there is no significant interaction effect of teaching strategies and gender on the achievement mean score of undergraduate students in Educational Management? 


\section{RESEARCH METHODS}

The research design used for this study was a quasi-experimental design which involved pretest-post test non equivalent group control design. The Chickering-Gamson Instructional Strategy was the experimental while the Lecture Teaching method was the control. This design is symbolically illustrated in the figure 1 :



Where, $\mathrm{O}_{1}$ and $\mathrm{O}_{3}$ represents pre-test

$\mathrm{O}_{2}$ and $\mathrm{O}_{4}$ represents post-test

$\mathrm{X}_{1}$ represents Chickering-Ganson Instructional Strategy (experimental Treatment)

$\mathrm{X}_{2}$ represents Chalk and Talk (Lecture) Teaching Method (control)

$\mathrm{E}=$ Experimental group

$\mathrm{C}=$ Control group

Fig. 1: Symbolic representation of the design.

\section{Area of the Study}

The area of the study is South-East geopolitical Zone, Nigeria. The zone is made up of five States, namely; Abia, Anambra, Ebonyi, Enugu and Imo. Each of these States has a Federal university, namely; Michael Okpara University of Agriculture, Umudike in Umuahia, Abia State. In Anambra State, there is Nnamdi Azikiwe University, Awka. Ebonyi State houses the Alex Ekwueme Federal University, Ndufu-Alike Ikwo. In Enugu State, there is the University of Nigeria, Nzukka and Imo State houses the Federal University of Technology, Owerri. Four of these Universities were used for the main study while one (Alex-Ekwueme Federal University, Ndufu-Alike Ikwo was used for the trial testing of the instrument of this study that produced data used to carry out the validation and reliability of the instrument. It implies that this University was not used for the main study.

\section{Population of the Study}

The population of this study comprised all the undergraduate students of the Department of Educational Foundations that offer Educational Management in the Universities in Abia, Anambra, Enugu and Imo States. The total number of students in Educational management in the four Universities was three hundred and twelve (312) (source: Various Faculties of Education of the Universities, 2018).

\section{Sample and Sampling Techniques}

The sample of the study consisted of one hundred and fifty nine (159) year I undergraduate students, made up of seventy two (72) males and eighty seven (87) females. This number was obtained from the intact classes of Educational Management of the different Universities during the implementation of the treatment for the study. A simple random sampling technique was used to assign two (2) Universities to the Experimental group and the remaining two (2) Universities to the Control group. This was done through balloting with replacement. 


\section{Instrument for Data Collection}

The instrument for data collection was a structured multiple objective items titled: Educational Management Achievement Test (EMAT). It had two sections: A and B. Section A consisted of Thirty-four (34) multiple choice objective items. Each test item was followed by four (4) options (A-D) from which the students were expected to select the correct alternative. Test items were based on Educational Management concepts that were taught during the implementation of the treatment (teaching). These included: meaning, nature and scope of Educational Management in Nigeria; differences between educational Management and Educational Administration, and goals and functions of Educational Management in Nigeria.

\section{Validation of the Instrument}

The EMAT was validated by three experts; two from Educational Management and one from Measurement and Evaluation, all from Alex Ekwueme Federal University, Ndufu-Alike Ikwo in Ebonyi State. None of the items was dropped after vetting. The EMAT was administered to 30 students for trial testing, which lasted for 40 minutes. The scores were used for items analysis on Discriminating power and Difficulty index. Items of Discriminating power of 0.40 and above as well as Difficulty index of $0.40-0.60$ were retained. From that analysis, four (4) items were rejected reducing the number of items to thirty (30). The content validity of the instrument was determined by using the 30 items of the instrument to prepare a test blueprint in line with the Bloom's domain levels: knowledge, comprehension, application, analysis, synthesis and evaluation.

\section{Reliability of the Instrument}

Data collected from the 30 items of EMAT instrument was subjected to a reliability testing through the application of Kuder-Richardson 20 formula for internal consistency. A reliability coefficient index of 0.91 was obtained showing very high internal consistency and the usability of the instrument for the study.

\section{Experimental Procedure}

Heads of Department of Educational Foundations where the course-Educational Management is offered in the Universities for the main study were officially contacted in writing for approval to use their Departments and Lecturers (as research assistants) for the study. Approval was granted and the Lecturers for the Chickering-Gamson instructional strategy (experimental) were trained while the Lecturers for the Lecture Teaching Method group (control) were not trained. The training lasted for one week on how to teach using Chickering-Gamson instructional strategy. During training, the researchers took time to explain to the Educational Management Lecturers in each experimental group the techniques involved in using Chickering-Gamson instructional strategy. They were given lesson notes prepared for the experimental group which they followed in their teaching. The Lecturers for the control group were not given any form of training but received lesson notes prepared for the control group that did not involve the use of Chickering-Gamson instructional strategy techniques. The teaching of the concepts (implementation of treatment) lasted for six weeks for both the experimental and control group.

\section{Method of Data Collection}

Data from the study were collected through pretest and post-test using EMAT. Pretest was administered to the subjects (students) before the treatment to measure the students' initial achievement in the subject matter. After the six weeks of treatment implementation, post-test was administered to the subjects. Data collected from the two tests were recorded 
separately and used for data analysis. The following variables were adequately controlled; teacher variable, Hawthorn effect, subject interaction, test effect and inter-group variables.

\section{Method of Data Analysis}

Research questions were answered using mean and standard deviation while the hypotheses were tested using Analysis of Covariance (ANCOVA). This was mainly for the analysis of significant difference between levels of treatment on the post-test scores using the pretest as covariates.

\section{RESULTS}

The results of data analysis according to research questions and hypotheses are presented in Tables.

\section{Research Question One}

What is the achievement mean score of undergraduate students taught Educational Management using Chickering-Gamson instructional strategy and those taught using the Lecture Teaching Method?

Table 1: Achievement Mean Score of Students based on Teaching Strategies

\begin{tabular}{|l|c|c|c|c|}
\hline \multicolumn{1}{|c|}{ Method } & $\mathbf{N}$ & $\underline{\mathbf{0}}$ & $\overline{\boldsymbol{X}}$ & S.D \\
\hline Chickering - Gamson Instructional Strategy & 6 & 5 & 68.15 & 6.71 \\
\hline Lecture Teaching Method & 9 & 4 & 36.88 & 13.22 \\
\hline
\end{tabular}

Based on the results in Table 1, the students in Chickering-Gamson Instructional Strategy group had a mean score of 68.15and a standard deviation of 6.71 while students in Lecture Teaching Method group had a mean score of 39.88 and standard deviation of 13.22. Therefore, the students in Chickering-Gamson Instructional Strategy group performed better (obtained a higher mean score) than students in Lecture Teaching Method group in Educational Management.

\section{Research Question two}

What is the achievement mean score of male and female undergraduate students taught Educational Management using Chickering-Gamson instructional strategy?

Table 2: Achievement Mean Score of Students in Chickering-Gamson Instructional Strategy based on Gender

\begin{tabular}{|c|c|c|c|c|c|c|c|c|}
\hline & \multicolumn{3}{|c|}{ Male } & \multicolumn{3}{|c|}{ Female } \\
\hline Method & $\mathbf{N}$ & $\underline{\mathbf{0}}$ & $\overline{\boldsymbol{x}}$ & $\mathbf{S . D}$ & $\mathbf{N}$ & $\underline{\mathbf{0}}$ & $\overline{\boldsymbol{x}}$ & S.d \\
\hline Chickering - Gamson Instructional Strategy & 3 & $\underline{1}$ & 68.71 & 12.58 & 3 & $\underline{5}$ & 67.65 & 13.93 \\
\hline
\end{tabular}

According to the results shown in Table 2, male students had a mean score of 68.71 and standard deviation of 12.58 while female students had a mean score of 67.65 and standard deviation of 13.93. Therefore, male students performed better than the female students since they (male students) had a higher mean score than the female students in Educational Management.

\section{Research Question Three}

What is the interaction effect of teaching strategies and gender on the achievement mean score of undergraduate students in Educational Management? 
Table 3: Achievement Mean Scores of Students Based on Interaction between Teaching Strategies and Gender

\begin{tabular}{|c|c|c|c|c|c|c|}
\hline & \multicolumn{4}{|c|}{ Male } & Female \\
\hline Method & $\mathbf{N}$ & $\underline{\mathbf{0}}$ & $\bar{x}$ & $\mathbf{N}$ & $\underline{\mathbf{o}}$ & $\bar{x}$ \\
\hline Chickering - Gamson Instructional Strategy & 3 & $\underline{1}$ & 68.71 & 3 & $\underline{4}$ & 67.65 \\
\hline Lecture Teaching Method & 4 & $\underline{1}$ & 39.92 & 5 & $\underline{2}$ & 39.83 \\
\hline
\end{tabular}

The results in Table 3 revealed that male students taught Educational Management using Chickering-Gamson Instructional Strategy had a mean score of 68.71 while their female counterparts taught with Lecture Teaching Method had a mean score of 67.65. In the same way, male students in using Lecture Teaching Method had a mean score of 39.92 while females in the same group had a mean score of 39.83.In distinction, male students achieved highrt mean scores in the two strategies. Based on these results, the researchers conclude that there is no interaction effect of the teaching strategies and gender on students' achievement mean scores in Educational Management.

\section{Hypotheses}

- $\mathbf{H O}_{1}$ : there is no significant difference in the achievement mean score of undergraduate students taught Educational Management using Chickering-Gamson instructional strategy and those taught using the Lecture Teaching Method.

Table 4: ANCOVA Results of Students Achievement Based on Teaching Strategies

\begin{tabular}{|l|c|c|c|c|c|c|}
\hline Source of Variation & Sum of Squares & Df & Mean Square & F & Sig. of. F & Alpha Level \\
\hline Covariate & 39033.434 & 1 & 39033.434 & 1053.138 & 0.000 & \\
\hline Pre-test & 39033.434 & 1 & 39033.434 & 1053.138 & 0.000 & \\
\hline Main Effects & 1261.774 & 1 & 1261.774 & 34.043 & 0.000 & \\
\hline Methods & 1261.774 & 1 & 1261.774 & 34.043 & 0.000 & 0.05 \\
\hline Explained & 40295.207 & 2 & 20147.604 & 543.590 & 0.000 & \\
\hline Residual & 5781.975 & 156 & 37.064 & & & \\
\hline Total & 46077.182 & 158 & 291.628 & & & \\
\hline
\end{tabular}

Significant at $\mathbf{P}<0.05$

From the result in Table 4, the significance of $\mathrm{F}$ (0.000) for instructional strategies (methods) is less than the alpha level of 0.05. Therefore, $\mathrm{HO}_{1}$ is rejected, meaning that there is a significant difference in the achievement means of students taught Educational Management using Chickering-Gamson Instructional strategy and those taught using the Lecture Teaching Method. Following the significance, multiple classification analysis was carried out to determine the actual contribution of the levels of treatment. The result based on adjusted mean is as shown in Table 5.

Table 5: Multiple Classification Analysis on Achievement Score of Students. Grand Mean = 51.44

\begin{tabular}{|l|c|c|c|c|c|}
\hline \multicolumn{1}{|c|}{ Variable + Category } & $\mathbf{N}$ & $\begin{array}{c}\text { Unadjusted } \\
\text { deviation }\end{array}$ & Eta & $\begin{array}{c}\text { Adjusted for independents + } \\
\text { covariates deviation }\end{array}$ & Beta \\
\hline Methods & & & & 5.34 & \\
\hline $\begin{array}{l}\text { Chickering-Gamson } \\
\text { Instructional Strategy }\end{array}$ & 65 & 16.71 & & -3.69 & \\
\hline Lecture Teaching Method & 94 & -11.56 & & & 0.26 \\
\hline & & & 0.82 & & 0.875 \\
\hline Multiple R Squared & & & & & 0.935 \\
\hline Multiple R & & & & & \\
\hline
\end{tabular}

From the result in Table 5, the grand mean is 51.44 for achievement. The Chickering-Gamson Instructional strategy had the highest adjusted mean score of 56.78 followed by the Lecture Teaching Method with an adjusted mean score of 47.75 . Treatment contributed $6.76 \%(0.26)^{2}$ of the variation (difference) in achievement while the remaining 
93.24\% was due to pretest measures or other unexplained sampling errors. Therefore, the gradation of achievement is Chickering-Gamson>Lecture Teaching Method.

- $\mathbf{H O}_{2}$ : there is no significant difference in the achievement mean score of male and female undergraduate students taught Educational Management using Chickering-Gamson Instructional strategy

Table 6: ANCOVA Results on Students' Achievement Based on Gender

\begin{tabular}{|c|c|c|c|c|c|c|}
\hline Source of Variation & Sum of Squares & Df & Mean Square & F & Sig. of. F & Alpha Level \\
\hline Covariate & 7985.375 & 1 & 7985.375 & 155.352 & 0.000 & \\
\hline Pre-test & 7985.375 & 1 & 7985.375 & 155.352 & 0.000 & \\
\hline Main Effects & 6.182 & 1 & 6.182 & 0.120 & 0.730 & \\
\hline Gender & 6.182 & 1 & 6.182 & 0.120 & 0.730 & 0.05 \\
\hline Explained & 7991.557 & 2 & 3995.779 & 77.736 & 0.000 & \\
\hline Residual & 3186.904 & 62 & 51.402 & & & \\
\hline Total & 11187.462 & 64 & 174.663 & & & \\
\hline
\end{tabular}

Not Significant at $\mathbf{p}<0.05$

Based on the result in Table $6, \mathrm{HO}_{2}$ is not rejected because the significance of $\mathrm{F}(0.730)$ for gender is greater than the alpha level of 0.05 . This means that there is no significant differences in the achievement mean score of male and female students taught using Chickering-Gamson Instructional Strategy. Following the non significance of the result of the test of significance of hypothesis 2 , multiple classification analysis was not carried out.

- $\mathbf{H O}_{3}$ : there is no significant interaction effect of teaching strategies and gender on the achievement mean score of undergraduate students in Educational Management.

Table 7: ANCOVA Results on Interaction Effects of Teaching Strategies and Genders

\begin{tabular}{|l|c|c|c|c|c|c|}
\hline Source of Variation & Sum of Squares & Df & Mean Square & F & Sig. of. F & Alpha Level \\
\hline Covariate & 39033.434 & 1 & 39033.434 & 1043.063 & 0.000 & \\
\hline Pre-test & 39033.434 & 1 & 39033.434 & 1043.063 & 0.000 & \\
\hline Main Effects & 1263.059 & 2 & 631.530 & 16.876 & 0.000 & \\
\hline Methods & 1261.774 & 1 & 1261.774 & 33.717 & 0.000 & \\
\hline Gender & 1.285 & 1 & 1.285 & 0.034 & 0.853 & \\
\hline 2-Way Interaction & 17.711 & 1 & 17.711 & 0.473 & 0.493 & \\
\hline Methods x Gender & 17.711 & 1 & 17.711 & 0.473 & 0.493 & 0.05 \\
\hline Explained & 40314.204 & 4 & 10078.551 & 269.322 & 0.000 & \\
\hline Residual & $\mathbf{5 7 6 2 . 9 7 9}$ & 154 & 37.422 & & & \\
\hline Total & $\mathbf{4 6 0 7 7 . 1 8 2}$ & 158 & $\mathbf{2 9 1 . 6 2 8}$ & & & \\
\hline
\end{tabular}

Not Significant at $\mathrm{p}<0.05$

The results of data analysis in Table 7 show that the significance of $F(0.493)$ for interaction of strategies and gender is greater than the alpha level of 0.05 . Therefore, $\mathrm{HO}_{3}$ is accepted. This means that there is no significant interaction effect of teaching strategies and gender on students' achievement mean scores in Educational management. Following the non-significance of the result of the test of significance of hypothesis 2, multiple classification analysis was not carried out.

In order to buttress the result of no interaction of teaching and gender, a graph based on posttest mean scores of male and female students was drawn which indicated that there was actually no interaction effect. This is shown by the parallel lines as seen in figure 1 below.

\section{SUMMARY OF FINDINGS}

The results of the study were summarized as follows: 
- Students in Chickering-Gamson Instructional Strategy group achieved higher mean score than those in Lecture Teaching Method group

- Male students had higher achievement than their female counterpart when taught with Chickering-Gamson Instructional Strategy.

- There was no interaction effect of the teaching strategies and gender on students' achievement mean score in Educational Management.

- The result of $\mathrm{HO}_{1}$ showed that there wasa significant difference in the achievement mean scores of students taught Educational Management using Chickering-Gamson Instructional Strategy and those taught using the Lecture Teaching Method. Therefore, $\mathrm{HO}_{1}$ was rejected.

- The result of $\mathrm{HO}_{2}$ showed that there was no significance difference in the achievement means scores of male and female students taught Educational Management concepts with Chickering-GamsonInstructional Strategy. Therefore, $\mathrm{HO}_{2}$ was not rejected.

- The result of $\mathrm{HO}_{3}$ showed that there was no significant interaction effect of teaching strategies and gender on students' achievement mean score in Educational Management.

- Therefore, $\mathrm{HO}_{3}$ was not rejected.

\section{DISCUSSION OF RESULTS}

The findings of the study based on the research questions that guided the study and the hypotheses tested are discussed, thus:

\section{Effect of Chickering-Gamson Instructional Strategy on Students' Achievement in Educational Management}

The research question one aimed at determining the effect of Chickering-Gamson Instructional Strategy on University Undergraduate students' achievement mean scores in Educational Management. The results of the analysis as indicated in Table 1showed that students in Chickering-Gamson Instructional Strategy group had a higher adjusted achievement mean score than students in the Lecture Teaching method group. From the results, students in the Chickering-Gamson Instructional Strategy group performed better than the students in the Lecture Teaching method group.

The result for students in Chickering-Gamson Instructional Strategy group is better because of the features of the strategies, thus: keeping of contact with faculty and the students may have enhanced students' intellectual commitment and encouraged learning as opined by Chickering and Ehramann (1996). The administrative responsibility of the faculty to ensure that contact between lecturers and students is improved, maintained and encouraged helped to promote students' creativity. This is corroborated by the view of Bain (2012). The strategy also provided platform for students to participate actively in a group; share ideas, explain their opinions, articulate their reasoning and expound their knowledge. The lecturers may have applied social grouping and association that promoted cooperation between lecturers and students thereby bringing a sense of high motivation to the students for their studies.These equally support the view of Chiu, Young, Liang and Chen, (2010). The active learning techniques in the strategy are essential elements that enhanced facilitation by lecturers during the activities carried out by the students. This is supported by Devline and Samarawickrema (2010). 
The strategy also provided feedback mechanism which acted as reinforcement in motivating students to know their areas of strength and weakness as suggested by Beard (2008) and Oche (2012) respectively. This finding is also in consonance with the report of Cakioglu (2014) and Ugodulunwa, Ogba and Igu (2017) who in their independent study establish that prompt feedback makes students assertive, promote self assessment and help students in ascertaining their ability level. The application of time on task characteristics of the strategy during the teaching-learning process may have made the teaching and learning very enjoyable for the categories of students with their individual differences. The time on task could have made it easy to allot adequate time on tasks to be done. This is also the opinion of Aydogdu (2012).

The result may have been improved by using this strategy because communicating high expectations to the students may have brought about the high positive attitude of the students in the activities of the strategy as recommended by Duarte (2013) and Skelton (2014). The result could have been enhanced greatly by the application of respecting diverse talents and ways of learning as provided by the strategy. This assertion agrees Smith and Valentine (2012) who asserted that students learn in unique way and their uniqueness should be respected. Ogba and Igu (2013) also maintained that teachers should be committed in respecting the diverse abilities in learners as this will promote performance.

The null hypothesis $1\left(\mathrm{HO}_{1}\right)$ tested the significant difference in the mean achievement score of students taught Educational Management using Chickering-Gamson Instructional Strategy and those taught using Lecture Teaching Method. The results of the test of significance as shown in Table 4 revealed that at 0.05 alpha level, $\mathrm{HO}_{1}$ was rejected, indicating a case of significance. The seven step procedures or principles of Chickering-Gamson Instructional Strategy clearly distinguish it from the Lecture teaching method thereby making it (Chickering-Gamson Instructional Strategy) a superior, innovative, effective and activity based strategy. This means that both strategies cannot be combined for the students. This finding agrees with the report of Jackson (2009) who finds significant difference in opinion of coordinators and learners in the use of Chickering-Gamson instructional strategy in teaching undergraduate students in Turkey Universities.

\section{Effects of Chickering-Gamson Instructional Strategy Instructional Strategy on the Achievement of male and female students in Educational Management}

The research question two (2) sought to determine the effects of Chickering-Gamson Instructional Strategy on the achievement mean scores of male and female students in Educational Management. The results of data analysis as indicated in Table 2 showed that male students using the Chickering-Gamson Instructional Strategy performed better than the female students. The result could have been so because male students showed more positive attitude towards subject matter than female students. Kousa, Kovanius and Aksela (2018) had equally opined that male students exhibit more positive attitude towards their study than female students. Again, the seven step procedures could have been a little cumbersome to the female students who are said not to be able to withstand pressure at work.

The null hypothesis $2\left(\mathrm{HO}_{2}\right)$ tested the significance of achievement mean scores of male and female student taught Educational Management using Chickering-Gamson Instructional Strategy. The test results as shown in Table 6 indicated that at alpha level of $0.05, \mathrm{HO}_{2}$ wasnot rejected. This means that there is no significant difference in the mean achievement scores of male and female students taught with Chickering-Gamson Instructional Strategy. 
On the contrary, the results are not in line with the work of Ezeoba (2013) which showed that there was a significant difference in the mean achievement score of male and female students exposed to Chickering-Gamson Instructional Strategy. He meant that gender is a significant factor in students' mean achievement.

\section{Interaction Effect between Teaching Strategies and Gender on Students' Achievement}

The research question three (3) aimed at determining the interaction effects between teaching strategies and gender on students' achievement in Educational Management. The result as shown in Table 3 revealed that there is no interaction effect of teaching strategies and gender because the male students had higher achievement in both the Chickering-Gamson Instructional Strategy and Lecture Teaching Method. The two strategies were more favourable to the male students only. This result is in line with the work of Eke (2017) which showed that male students achieved high than their female counterpart, contrary to the view of On wuachu (2015), that there was no significant difference in the achievement of students based on gender.

The null hypothesis 3 tested the significant interaction effect of achievement in chemistry. From the results in Table 7 , the significance of $\mathrm{F}(0.493)$ for methods and gender is greater than the alpha level of 0.05 , hence, $\mathrm{HO}_{3}$ is accepted. This means that there is no significant interaction effect of teaching strategies and gender on students' achievement mean scores in Educational Management. This suggests that Chickering-Gamson Instructional Strategy also favour single sex schools where interaction between males and females is not possible.

\section{EDUCATIONAL IMPLICATIONS}

The results of this study have notable educational implications, inter-alia:

- The use of Chickering-Gamson Instructional Strategy resulted in higher academic achievement by the undergraduate students. This implies that when it is used in teaching and learning situation, it will effectively improve students' academic achievement.

- Chickering-Gamson Instructional Strategy seems to have the ability to reduce gender differences as it favoured both sexes. It should be noted that it produced no significant difference based on gender; hence it should be used on male and female students.

- The result on interaction effect is encouraging as it could serve as an instructional strategy for single sex institutions since it did not produce any significant interaction effect.

\section{RECOMMENDATIONS}

Based on the results, the following recommendations are made:

- Chickering-Gamson Instructional Strategy should be used by Educational Management Lecturers in their teaching.

- Chickering-Gamson Instructional Strategy is recommended for use for both male and female Educational Management students as it favours both sexes.

- Curriculum organizations like Nigerian Educational Research and Development Council (NERDC) and especially National University Commission (NUC) should include Chickering-Gamson Instructional Strategy as recommended strategy for teaching in Universities 
- Future researchers should consult this material/paper for use thereby popularizing its contents.

\section{LIMITATIONS OF THE STUDY}

The limitations to this study include the following:

- Teaching experiences of the lecturers used as research assistants may have introduced errors in the result obtained as the Lecturers had different years of teaching experiences.

- Lack of control of qualification of Lecturers used as research assistants for the study was a limitation that may have introduced errors in the results obtained.

- The instrument used could have introduced error in the result, as it did not produce a hundred percent reliability, suggesting some lapses in its structure.

\section{CONCLUSIONS}

This study determined the effects of Chickering-Gamson Instructional Strategyon University undergraduate students' achievement in Educational management in Federal Universities in South-East Geo-political Zone, Nigeria. The relevance of Educational management to economic and business development of Nigeria made it a challenge to the researchers and necessitated the research. This was as a result of poor achievements of Undergraduate year one students in their semester examinations. Educational management Lecturers have applied various strategies to teach the course and yet the ugly trend (low achievement) has not abated.

The researchers adopted Chickering-Gamson Instructional Strategy in their research which produced higher achievement in the students' mean scores in Educational Management in the used Universities. Findings also showed that Chickering-Gamson Instructional Strategy favoured male students while there was no interaction effect. Based on the results recommendations were made such that the researchers are confident that when implemented, the poor achievement in Educational Management will be eradicated promptly.

\section{ACKNOWLEDGEMENTS}

The researchers are very highly appreciative of the kind gesture of Honourable Senator Obinna Ogba Foundation for providing financial grant that made the field work a success. They are also grateful to the Universities used for the field work of this study. The researchers state unequivocally that there is no conflict of interest among them in the entire work carried out.

\section{REFERENCES}

1. Asghar, N. (2014). Faculty student interaction and educational outcomes: A comparison of first generation and continuing generation students. A Dissertation of Brigham University.

2. Aydogdu, A., Doymus, K. and Simsek, U. (2012).Instructors' practice level of Chickering and Gamson learning principles.MevlanaInternational Journal of Education (MIJE), 2(2)11-24. Retrieved from http://mije.mevlana.edu.tr/ 22ndJanuary, 2018.

3. Bain, K. (2012). What the best college student do. Cambridge, MA: BellnapPress/Harvard University Press.

4. Beard, K. L. S. (2008). An exploratory study of academic optimism and flow of elementary school teachers.Doctoral thesis, the Ohio State University. 
5. Biggs, J. (2004). Teaching for quality learning at University: What the student does (4th edn.) ,Berkshire:Open University Press.

6. Brookfield, S. D. (2006). The skillful teacher: On technique, trust, and responsiveness in the classroom (2nd edn.), San Francisco, CA:.Jossey-Bass.

7. Cakiroglu, U. (2014). Evaluating students' perspectives about virtual classrooms with regard to seven principles of good practice. South African Journal of Education, 34(2), 1-19.

8. Chickering, A. W \&Gamson, Z. F. ( 1987). Seven principles for good practice in undergraduate education. UAS: AAHE Bulletin. 39(7) 3-7.

9. Chickering, A.W., \&Ehrmann, S.C. (1996).Implementing the seven principles: Technology as a lever, AAHE Bulletin, 49(2), $3-6$.

10. Chiu, C. H., Yang, H. Y., Liang, T. H., \& Chen, H. P. (2010).Elementary students' participation style in synchronous online communication and collaboration behavior.Information Technology, 29(6), 571-586.

11. Devlin, M. \&Samarawickrema, G. (2010).The criteria of effective teaching in a changing higher education context.Higher Education Research and Development 20(2), 111-124

12. Duarte, F. P. (2013) Conceptions of good teaching by good teachers: Case studies from an Australian University. Journal of University Teaching \& Learning Practice, 10(1), 2013.Available at:http://ro.uow.edu.au/jutlp/vol10/iss1/5.

13. Ewah, P. N. (2016). Effects of cooperative learning strategies on senior secondary school students' achievement in Biology in Afikpo Education Zone.Unpublished MED Dissertation,Ebonyi State University Abakaliki.

14. Igwe I.O. (2013). Principle of science and science teaching in Nigeria.Ogui New Layout, Enugu: Jones Communication Publishers.

15. Igwe, I. O.\&Igwe, C. I.(2016). Methodology andconceptual dynamics of science teaching and learning.Abakaliki: Ugwusons Printers \& $\mathrm{Co}$

16. Jackson, G.U. (2009). Effectiveness of guided inquiry laboratory experiment on senior secondary schools students' academic achievement in volumetric analysis.American Journal of Educational Research. 5 (7), 717-724.

17. Kahreci, P., (2015). Leisure College USA: The decline in student study time. Education Outlook.No. 7.

18. Light, G. \& Calkins, S. (2008). The experience of faculty development: Patterns of variations in conceptions of teaching. International Journal for Academic Development, 13, 24-70.

19. Lombardi, (2011)

20. Meyer, (2009).Personal study of science process skills in a general Physics classroom.Master of Arts Education and Natural Sciences (unpublished), Environmental Education. Cape Stone.

21. Mudassir Khan, MohdAyyoob. "The scope of E-learning in the computer science \& technologies." International Journal of Computer Science Engineering and Information Technology Research (IJCSEITR) 6.6 (2016): 93-98.

22. Nwagbo, C. \&Chikelu, M. (2001).The relative efficacy of guided inquiry and expository methods on achievement in Biology of different levels of scientific literacy.Journal of the Science Teachers Association of Nigeria. 36(1\&2), 47-51.

23. Nzewi, U. M. (2010). It is all in the brain of gender and achievement in science and technology education. 51st Inaugural lecture: Department of Science Education. University of Nigeria Nsukka, $18-32$ 
24. Oche, E. S., (2012). Assessing the effect of prompt feedback as a motivational strategy on students' achievement in secondary school mathematics, Educational Research, 3(4), 371-379.

25. Ogba, F.N. and Igu, N.C.N (2013). Quality education in Nigeria: The need for quality control in teacher production in Ebonyi State. African Journal of Pedagogy, 5 (2) 75-90

26. Okeke, E. A. (2007). Making science education accessible to all.23rd Inaugural lecture.Department of Science Education.University of Nigeria Nsukka.

27. Okoro, A. O. (2011). Effects of interaction patterns on achievement and interest in biology among secondary school in Enugu State, Nigeria. Unpublished MED Dissertation Department of Science Education.University of Nigeria Nssuka.

28. Okoronka, Augustine Ugwumba, and Kodjo Donkor Taale. "Analogies, Problem-Solving And Concept Mapping Instructional Strategies As Determinants Of Senior Secondary School Students'achievement In Wave Concepts In Adamawa State, Nigeria." International Journal of Humanities and Social Sciences (IJHSS) 3.3 (2014): 33-46.

29. Oludipe, E. N. (2012). Enhancing students' achievement in expository writing using collaborative learning.Journal of Applied Literacy and Reading.6 (2) 66-80

30. Palloff, R. M., \& Pratt, K. (2009).Assessing the online learner:Resources and strategies for Faculty. San Francisco, CA: Jossey Bass.

31. Prosser \&Trigwell (1999). Beyond feedback: Developing student capability in complex appraisal. Assessment \& Evaluation in Higher Education, 35(5), 535-550

32. Samarawickrema, G. (2010).Comparison of students \& instructor perceptions of best practices in online technologu courses.Merlot Journal of Online Learning \& Teaching 4(4) 477-489.

33. Sherry, J. (2014). Applying the seven principles of good practice:Technology as a liver in an online research course. Journal of Interactive Online Learning www.ncolr.org/jiol. 13(2) 41-49. Retrieved 22nd March 2018

34. Skelton (2004).Understanding "teaching excellence" in higher education: A critical evaluation of the National Teaching Fellowships Scheme. Studies in Higher Education, 29(4), 451-468

35. Smith \& Valentine, ( 2012).Learning to teach in higher education (2 ed.), London:Routledge-Falmer.

36. Sitompul, Dahlan RP, and PoltakSihombing. "Designing Learning Media Of Control Based On Micro Controller 8051 By Using The MCU 8051 Ide To Support The Implementation Of Active Learning In Higher Education-Alfhe (Active Learning For Higher Education)." International Journal IJECIERD, ISSN (P) (2014).

37. Srinivasa Rao, A. B., P. M. Kumar, and P. S. Aithal. "Strategic Planning in Higher Education Institutions: A Case Study of SIMS-VISION 2025." International Journal of Educational Science and Research (IJESR) ISSN (P) (2015): 2249-6947.

38. Ugodulunwa, C. A, Ogba, F. N and Igu, N. C. N. (2017). Assessment for learning: university teachers understanding and practices in Nigeria. A Paper Presented at the 35thAnnual Conference of the Association for Educational Assessment in Africa (AEAA) Held from 7-11 August, 2017 at the Speke Resort and Conference Centre, Munyonyo Kampala, Uganda

39. Wayant, P. (Ed.). (2003). Teaching and learning are lifelong journeys: Thoughts on the art of teaching and the meaning of education. Boulder, CO: Blue Mountain Press

40. Wikipedia (2010). Academic achievement based instructional strategy. Hppts//en/programming.Hppt//sites.google.com. Retrieved April, 2018 